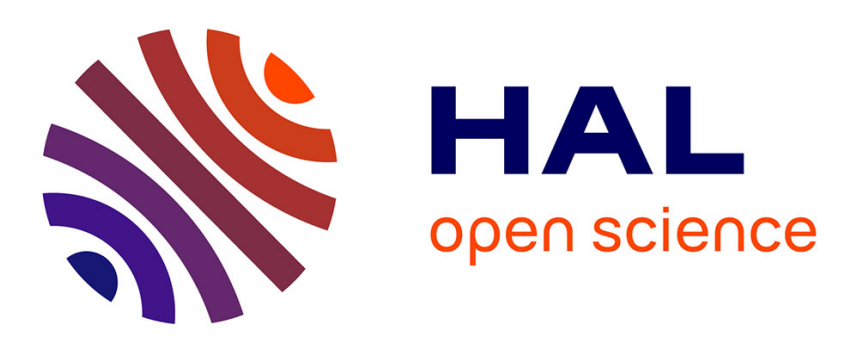

\title{
Four years of DNA barcoding: current advances and prospects.
}

Lise Frézal, Raphael Leblois

\section{To cite this version:}

Lise Frézal, Raphael Leblois. Four years of DNA barcoding: current advances and prospects.. Infection, Genetics and Evolution, 2008, 8 (5), pp.727-36. 10.1016/j.meegid.2008.05.005 . mnhn-00392451

\section{HAL Id: mnhn-00392451}

\section{https://hal-mnhn.archives-ouvertes.fr/mnhn-00392451}

Submitted on 8 Jun 2009

HAL is a multi-disciplinary open access archive for the deposit and dissemination of scientific research documents, whether they are published or not. The documents may come from teaching and research institutions in France or abroad, or from public or private research centers.
L'archive ouverte pluridisciplinaire HAL, est destinée au dépôt et à la diffusion de documents scientifiques de niveau recherche, publiés ou non, émanant des établissements d'enseignement et de recherche français ou étrangers, des laboratoires publics ou privés. 
14 years of DNA barcoding : current advances and prospects

2

3

$4 \quad$ Authors : Lise Frézal ${ }^{1}$, Raphael Leblois ${ }^{2 *}$

51 Laboratoire de Biologie intégrative des populations, Ecole Pratique des Hautes Etudes, Paris,

6 France

72 Unité Origine, Structure et Evolution de la Biodiversité UMR 5202 CNRS/MNHN, Muséum

8 National d'Histoire Naturelle, Paris, France

$9 \quad$ * Corresponding author (Phone: +33 (0)1 407933 49; Fax: +33 (0)1 407933 42; Email:

10 leblois@mnhn.fr)

11

12

13 


\title{
Abstract
}

L. Frézal and R. Leblois - 4 years of DNA barcoding: current advances and prospects -

16 Infection, Genetics and Evolution

17

18

\section{.} 0

Research using cytochrome $c$ oxidase barcoding techniques on zoological specimens was initiated by Hebert et al. (2003). By March 2004, the Consortium for the Barcode of Life started to promote the use of a standardized DNA barcoding approach, consisting of identifying a specimen as belonging to a certain animal species based on a single universal marker: the DNA barcode sequence. Over the last four years, this approach has become increasingly popular and advances as well as limitations have clearly emerged as increasing amounts of organisms have been studied. Our purpose is to briefly expose DNA Barcode of Life principles, pros and cons, relevance and universality. The initially proposed Barcode of life framework has greatly evolved, giving rise to a flexible description of DNA barcoding and a larger range of applications.

Index Key words: DNA barcode, cytochrome $c$ oxidase, COI, DNA taxonomy, species (3)

\author{
identification, international species databank, BOLD
}


Frézal, L., Leblois, R. Infection, Genetics and Evolution

\section{1- Introduction}

Species identification and classification have traditionally been the specialist domain of taxonomists, providing a nomenclatural backbone and a key prerequisite for numerous biological studies. Indeed, today's society has to resolve many crucial biological issues, among which are the need to maintain biodiversity, to ensure bio-security, to protect species and to avoid pandemics. The achievement of such goals and the success of subsequent action programs require efficient global networks and rely on our capacity to identify any described species. As Dayrat (2005) clearly expressed, 'delineating species boundaries correctly - and also identifying species - are crucial to the discovery of life's diversity because it determines whether different individual organisms are members of the same entity or not'. The identification of species depends on the knowledge held by taxonomists whose work cannot cover all taxon identification requested by non specialists. To deal with these difficulties, the 'DNA Barcode of Life' project aims to develop a standardized, rapid and inexpensive species identification method accessible to non-specialists (i.e. non-taxonomists).

The idea of a standardized molecular identification system emerged progressively during the 1990s with the development of PCR-based approaches for species identification. Molecular identification has largely been applied to bacterial studies, microbial biodiversity surveys (e.g. Woese, 1996; Zhou et al., 1997) and routine pathogenic strains diagnoses (e.g. Maiden et al., 1998, Sugita et al., 1998; Wirth et al., 2006) due to a need for culture-independent identification systems. PCR-based methods have also been frequently used in fields related to taxonomy, food and forensic molecular identification (Teletchea et al., 2005) and for identification of eukaryotic pathogens and vectors (e.g. Walton et al., 1999). Several universal systems for molecular-based identification have been used for lower taxa (e.g. nematodes, Floyd et al., 2002) but were not successfully implemented for broader scopes. The Barcode of Life project soon after became that attempt, aiming to create a universal system for a eukaryotic species inventory based on a standard molecular approach. It was initiated in 2003 by researchers at the University of Guelph in Ontario, Canada (http://www.barcoding.si.edu) and promoted in 2004 by the international initiative 'Consortium for the Barcode of Life' (CBOL). By then, it had more than 150 member organizations from 45 countries including natural history museums, zoos, herbaria, botanical gardens, university departments as well as private companies and governmental organizations. The DNA barcode project does not have the ambition to build the tree of life nor to perform molecular taxonomy (Erbach and Holdrege, 2005; Gregory, 2005), but rather to produce a simple diagnostic tool based on strong taxonomic knowledge that is collated in the DNA barcode reference library (Schindel and Miller, 2005). The DNA Barcode of Life Data System (BOLD, http://www.boldsystems.org) has 
progressively been developed since 2004 and was officially established in 2007 (Ratnasingham and Hebert, 2007). This data system enables the acquisition, storage, analysis and publication of DNA barcode records.

In the present paper we briefly review the current state of DNA barcode advances, trends and pitfalls. The main methods of the DNA barcoding approach are given. The feasibility of a universal barcoding approach and interest in the DNA barcoding approach for microbial studies are discussed.

\section{2- The DNA Barcoding approach: definitions and objectives}

\section{2-1 DNA barcode definition and primary objectives}

The DNA barcode project was initially conceived as a standard system for fast and accurate identification of animal species. Its scope is now that of all eukaryotic species (Hebert et al., 2003; Miller, 2007). The DNA barcode itself consists of a 648 bp region 58-705 from the 5'-end of the cytochrome $c$ oxidase 1 (COI) gene using the mouse mitochondrial genome as a reference. It is based on the postulate that every species will most likely have a unique DNA barcode (indeed there are $4^{650}$ possible ATGC-combinations compared to an estimated 10 million species remaining to be discovered, Wilson, 2004) and that genetic variation between species exceeds variation within species (Hebert et al., 2003; Hebert, 2004a). The two main ambitions of DNA barcoding are to (i) assign unknown specimens to species and (ii) enhance the discovery of new species and facilitate identification, particularly in cryptic, microscopic and other organisms with complex or inaccessible morphology (Hebert et al., 2003).

\section{2-2 When is the DNA barcode useful?}

Access to a public reference database of taxa allowing identification of a wide range of species will be beneficial whenever accurate taxonomic identifications are required. The DNA barcode can in this way be of great support to numerous scientific domains (e.g. ecology, biomedicine, epidemiology, evolutionary biology, biogeography and conservation biology) and in bio-industry. The cost and time-effectiveness of DNA barcoding enables automated species identification, which is particularly useful in large sampling campaigns (e.g. Craig Venter's Global Ocean sampling team, Rusch et al., 2007). In this way, DNA barcoding could also improve large surveys aiming at unknown species detection and identification of pathogenic species with medical, ecological and 
agronomical significance (Armstrong and Ball, 2005; Ball and Armstrong, 2006). Besides, it is important to be able to recognize, detect and trace dispersal of patented organisms in agrobiotechnology, either to certify the source organism (e.g. truffles, Rastogi et al., 2007) or secure intellectual property rights for bioresources (Gressel and Ehrlich, 2002; Kress and Erickson, 2007; Taberlet et al., 2007).

One obvious advantage of DNA barcoding comes from the rapid acquisition of molecular data. As a contrast, morphological data gathering can be time consuming, in some cases totally confusing and in others, almost impossible (e.g. Dinoflagellate taxonomy, Litaker et al., 2007; diatomea, Evans et al., 2007; earthworms, Huang et al., 2007). Furthermore, in three important situations, relevant species identification must necessarily be molecular-based. First, in determining the taxonomic identity of damaged organisms or fragments of (e.g. goods, food and stomach extracts). The DNA barcoding tool is thus potentially useful in the food industry, diet analyses, forensic sciences and in preventing illegal trade and poaching of endangered species (e.g. fisheries, trees, bushmeat). Second, molecular-based identification is necessary when there are no obvious means to match adults with immature specimens (e.g. fish larvae, Pegg et al., 2006; amphibians, Randrianiaina et al., 2007; coleoptera, Caterino and Tishechkin, 2006; Ahrens et al., 2007; fungal sexual stage, Shenoy et al., 2007). The third case is when morphological traits do not clearly discriminate species (e.g. red algal species, Saunders, 2005; fungal species, Jaklitsch et al., 2006; and field-collected mosquito specimens, Kumar et al., 2007), especially when size precludes visual identification (i.e. 'unseeable animals', Blaxter et al., 2005; Webb et al., 2006) or if species have polymorphic life cycles and/or

\section{2-3 DNA Barcoding as a driving force in biological sciences}

More than being a species identification tool for non specialists, DNA barcoding is also of interest to specialists. To achieve the CBOL objectives, species have to be taxonomically described

132 before their deposit in BOLD, which leads researchers to resolve analytical, technical and 133 fundamental issues beforehand. It also brings together (and complements) taxonomy, molecular 134 phylogenetics and population genetics (Hajibabaei et al., 2007b). According to Rubinoff and Holland (2005), DNA barcoding can be regarded as a 'tremendous tool' to accelerate species

136 discovery and initiate new species descriptions (DeSalle et al., 2005; DeSalle, 2006). Moreover, it 137 re-opens the debate on species concepts (Fitzhugh, 2006; Rubinoff et al., 2006b; Balakrishnan, 2007; 138 Miller, 2007; Vogler and Monaghan, 2007). Unlike other well-known sequence libraries (e.g. 
$139 \mathrm{NCBI}$ ), BOLD is an interactive interface where deposited sequences can be revised and 140 taxonomically reassigned. The compiling of sequences, from one or few common loci improves 141 synergic studies at large geographic scales and across numerous genera (Hajibabaei et al., 2007b). 142 Such information on the global distribution of species, their genetic diversity and structure will 143 enhance the speed and effectiveness of local population studies.

\section{3- Advances in Barcoding}

\section{3-1 State of the art}

By March 2008, the total available DNA Barcode records were at 363,584 sequences $(50,039$ species), of which 136,338 sequences $(13,761$ species) satisfied DNA barcoding criteria (i.e. minimum sequence length of $500 \mathrm{bp}$ and more than 3 individuals per species). At this date, more than $65 \%$ of all barcoded specimens had been collected in the last five years. The majority of the specimens (over 98\%) are from the animal kingdom with more than $65 \%$ representing Insecta. The International Barcode of Life project (iBOL) is now under development by the new Canadian International Consortium Initiative (ICI). Researchers from 25 countries will be involved in this large-scale and collaborative program, which aims at building a comprehensive DNA barcode registry for eukaryotic life. The program's starting date is tentatively set at January 2009 and within the first 5-year period there are plans to acquire DNA barcode records for 5 million specimens representing 500,000 species (out of more than an estimated 10 million species to be discovered).

So far, the COI gene has proved to be suitable for the identification of a large range of animal taxa, including gastropods (Remigio and Hebert, 2003), springtails (Hogg and Hebert, 2004), butterflies (Hebert et al., 2004a; Hajibabaei et al., 2006a), birds (Hebert et al., 2004b; Kerr et al., 2007), mayflies (Ball et al., 2005), spiders (Greenstone et al., 2005), fish (Ward et al., 2005), ants (Smith et al., 2005), Crustacea (Costa et al., 2007) and recently, diatomea and Protista (Evans et al., 2007). Hajibabaei et al. (2006a) showed that $97.9 \%$ of 521 described species of Lepidoptera possess distinct DNA barcodes and furthermore that the few instances of sequence overlap of different species involve very similar ones.

The efficiency of DNA barcoding has been reported in the detection and description of new cryptic species (Hansfield and Hansfield, 2006; Smith et al., 2006b; Anker et al., 2007; Bucklin et al., 2007; Gomez et al., 2007; Pfenninger et al., 2007; Tavares and Baker, 2008) and of sibling species (Hogg and Hebert, 2004; Amaral et al., 2007; Van Velzen et al., 2007). This identification tool can clearly give support to improve classifications and to critically examine the precision of 
morphological traits commonly used in taxonomy. Indeed, several studies have already illustrated the advances provided by the iterative processes between morphological- and DNA barcode- based studies in taxonomy (Hebert et al., 2004a; Hebert and Gregory, 2005b; Page et al., 2005; Carlini et al., 2006; Smith et al., 2006a; Smith et al., 2007; Van Velzen et al., 2007).

\section{3-2 New insights into ecology and species biology}

New insights into ecology and species biology have already emerged from the DNA barcoding project. For example, the identification of organisms contained in stomach extracts allows the elucidation of wild animal diets, especially when behavioural studies are not feasible (e.g. Krill diets, Passmore et al., 2006; affirmation of polyphagy of the moth Homona mermerodes, Hulcr et al., 2007; Xenoturbella bocki diet, Bourlat et al., 2008). DNA barcoding could also become an efficient tool to clarify host-parasite and symbiotic relationships (Besansky et al., 2003) and in turn give new insights on host spectra, as well as on the geographical distributions of species (host, parasites and/or endangered species). Moreover, the tool is suitable to elucidate the symbiont and parasite transmission pathways from one host generation to the next as illustrated in the interaction of beetles (Lecythidaceae) with their endosymbiotic yeasts (Candida spp. clades and other undescribed yeast species) (Berkov et al., 2007). Molecular dating of symbiotic relationships can also be deduced using barcoding tools (Anker et al., 2007).

\section{3-3 Technical advances in barcoding}

The purpose of the DNA barcoding project is to rapidly assemble a precise and representative reference library. Thus it is based on conventional and inexpensive protocols for DNA extraction, amplification and sequencing. With time, the reference library will become increasingly useful, enabling the rapid identification of low taxonomic level taxa with specific short-DNA sequences (i.e. mini-barcode 100bp, Hajibabaei et al., 2006c; 300 bp, Min and Hickey, 2007.). It has been shown that species identity can be validated or inferred from a small number of polymorphic positions within the COI-barcode ('microcoding' of 25bp, Summerbell et al., 2005; DNA arrays-based identification, Hajibabaei et al., 2007; SNP-based discrimination, Xiao et al., 2007). Other new molecular technologies used in bioengineering (e.g. silicon-based microarrays, nylon membranebased macroarrays, etc.) are becoming cheaper and may be integrated into the 'second step of DNA barcoding' (Summerbell et al., 2005). Furthermore, new sequencing techniques such as 
208 pyrosequencing (454, Solexa, SOLID) enable rapid and representative analyses of mixed samples 209 (e.g. stomach contents, food, blood or water columns. Largely used in the emerging field of 210 metagenomics, this advance could be promising for future DNA barcoding initiatives.

211 DNA barcoding could also be used as a technical enhancer. Indeed, one condition for data 212 submission to BOLD is the conservation of entire morphological reference for species (voucher). 213 Indeed, new techniques of non-destructive DNA extraction from recently collected specimens have 214 already been developed (Pook and McEwing, 2005; Hunter et al., 2007; Rowley et al., 2007) and 215 additional improvements in specimen conservation may arise. One major drawback of molecular216 based studies as for example DNA barcoding is our incapacity to extract DNA from specimens 217 conserved in formalin. Indeed, museum collections of animals represent the major part of voucher 218 specimens from which species have been described and most of these are conserved in formalin. The 219 ultimate challenge is to find the appropriate ways to extract DNA from formalin-conserved 220 specimens and harvest DNA barcodes from them.

4- What can be learnt from the limitations of DNA barcoding?

Despite the promises of the global barcoding initiative, some crucial pitfalls must be mentioned. We believe that these limitations should be clearly identified and resolved in the library

\section{4-1 The under-described part of biodiversity}

The sampling shortage across taxa can sometimes lead to 'barcoding gaps' (Meyer and Paulay, 2005), which highlights the care that must be accorded to sampling quality during the database construction phase (Wiemer and Fiedler, 2007). The individuals chosen to represent each taxon in the reference database should cover the major part of the existing diversity. Indeed, in the interrogation of BOLD, identification difficulties arise when the unknown specimens come from a currently under-described part of biodiversity (Rubinoff, 2006; Rubinoff et al., 2006). Meyer and Paulay (2005) estimated the error rates for specimen assignment in well-characterized phylogenies and in partially known groups. They showed that the DNA barcode exclusively promises robust specimen assignment in clades for which the taxonomy is well understood and the representative 
241 specimens are thoroughly sampled. Their conclusions are totally concordant with the example of the

242 Muntjac described in DeSalle et al. (2005).

\section{4-2 Inherent risks due to mitochondrial inheritance}

The diversity of mitochondrial DNA (mtDNA) is strongly linked to the female genetic structure due to maternal inheritance. The use of mitochondrial loci can thus lead to overestimate sample divergence and render conclusions on species status unclear. For instance, in Homona mermerodes (Lepidoptera) mtDNA polymorphism is structured according to the host plants on which females feed, and the two clades produced by phylogenetic analyses are artefacts of female nutritional choice (Hulcr et al., 2007). Heteroplasmy and dual uniparental mitochondrial inheritance (e.g. Mussels, Terranova et al., 2007) are further misleading processes for mitochondrion-based phylogenetic studies.

The mitochondrial inheritance within species can also be confounded by symbiont infection.

255 Firstly, indirect selection on mitochondrial DNA arises from linkage disequilibria with endosymbionts, either obligate beneficial micro-organisms, parasitically- or maternally- inherited symbionts (Funk et al., 2000; Whitworth et al., 2007). Such symbionts are very common in arthropods (e.g. Wolbachia infects at least $20 \%$ of Insecta and $50 \%$ of spiders, Hurst and Jiggins, 2005; Cardinium infects around 7\% of arthopods, Weeks et al., 2007) and are probably widespread in many other Metazoa. Secondly, interspecific hybridization and endosymbiont infections can generate transfer of mitochondrial genes outside an individual's evolutionary group (Dasmahapatra and Mallet, 2006). Examples are the cross-generic mitochondrial DNA introgression observed between Acreae (Lepidoptera) and Drosophila (Diptera) coming from the vertically transmitted Wolbachia (Hurst and Jiggins, 2005), or the cross-kingdom horizontal mtgene transfer detected between sponges and their putative fungal symbionts (Rot et al., 2006). Finally, one host species can bear different symbionts (e.g. european populations of Adalia bearing three symbionts, Spiroplasma, Rickettsia and Wolbachia, Hurst et al., 1999), leading to intraspecific (i.e. inter-population) variation in mtDNA sequences.

In all these cases, nuclear loci are required to resolve phylogenetic relationships and may serve as a validating tool during the database construction stage. Besides, special care must be accorded to the compilation of reference sequences (i.e. DNA barcode), especially for species with already known disturbed mitochondrial inheritance. The presence of such potentially misleading effects should be explicitly indicated in the BOLD. However, unknown endosymbionts or exclusive 
274 causes of mtDNA inheritance disturbance could also be revealed during the DNA barcoding

275 database filing.

\section{4-3 Nuclear copies of COI (NUMTs)}

Nuclear mitochondrial DNAs (NUMTs) are nuclear copies of mitochondrial DNA sequences that have been translocated into the nuclear genome (Williams and Knowlton, 2001). In eukaryotes, the number and the size of NUMTs are variable, ranging from none or few in Anopheles, Caenorhabditis and Plasmodium, to more than 500 in humans, rice and Arabidopsis (Richly and Leister, 2004). As reported by Ann Bucklin (Oral comm., the $3^{\text {rd }}$ international Cons. Gen. symposium, New York, 2007) using DNA barcoding in investigations on marine zooplankton, and by Lorenz et al. (2005) performing primate DNA barcoding, nuclear COI copies can sometimes greatly complicate the straightforward collection of mitochondrial COI sequences. Disturbance due to NUMTs must be seriously considered, in both DNA barcode library construction and further specimen identification. Owing to their particular codon structure, non-synonymous mutations, premature stop codons and insertion-deletions (Strugnell and Lindgren, 2007), NUMTs can be recognized in the sequence and in the amino acid alignments. In the sequence acquisition stage, NUMTs can be detected by the sequence checking process proposed in BOLD (i.e. rejection of inconsistent amino acid alignment), and in such cases, their occurrence should be referenced in BOLD. Only recently integrated NUMTs that are difficult to detect (Thalmann et al., 2004), could be ignored. Although it is more difficult, it is nevertheless possible to get the true mtCOI sequence of voucher specimens with the reverse transcription (Collura et al., 1996). In the diagnostic stage, there may be cases where NUMT occurrence is unknown, which highlights the care that should be taken

\section{4-4 Rate of evolution in COI}

The rate of genome evolution (mitochondrial or nuclear) is not equal for all living species. Notably, molluscs have a higher evolutionary rate than other bilateral metazoans (Strugnell and Lindgren, 2007). In contrast, diploblast sponges and cnidarians have an evolutionary rate 10-20 times slower than in their bilaterian counterparts, a consequence of which is the lack of COIsequence variation that prevents distinction below the family level (Erpenbeck et al., 2006). The rate 
308 of evolution can even differ at the ordinal level, as shown between six dermapteran (Insect) species

309 (Wirth et al., 1999). In the same way, the level of variation in mitochondrial sequences in the plant

310 kingdom excludes species identification based on COI sequence polymorphism (Kress et al., 2005).

312 More generally, the lack of resolving power of COI-sequence reported for some taxa has led the 313 CBOL to envisage the transition from the primary single-gene method (i.e. BARCODE) to a multi314 region barcoding system, when it is justified (i.e. in cases where COI is not species specific, or for 315 taxa with low mitochondrial evolutionary rates) taxon-specific reference regions (i.e. nuclear plus/or 316 organelle genes), also called non-COI barcode (Bakker, Second International Barcode of Life 317 Conference, TAIPEI, September 2007).

\section{4-5 The intra-specific geographical structure should be taken into account}

Geographical structure, if ignored, can blur and distort species delineation. Actually, high rates of intraspecific divergence can derive from geographically isolated populations (Hebert et al., 2003), and thus, must be considered in the setting up of the DNA barcode reference database. This point stresses a key challenge for the DNA barcoding initiative, from both the fundamental and analytical points of view. What is the boundary between a population and a species? Does it exist? To solve this issue, wide-ranging intra-specific sampling should be integrated in the reference database, and one must consider species boundaries not as a definitive but as a revisable concept. The relevance of the reference DNA barcode database depends on the exhaustiveness of intra-taxon sampling.

To prevent misleading results, the current data format for submission to BOLD should be complemented with new fields related to the limitations mentioned above (i.e. NUMT occurrence, known endosymbiont, available insight on molecular clock, genetic structure and geographical distribution). Besides the biological limitations, DNA barcoding raises analytical and statistical issues. 
The main and unambiguous objective of DNA barcoding analysis is to assign one query sequence to a set of referenced tagged-specimen sequences extracted from BOLD. The method currently used in BOLD combines similarity methods with distance tree reconstruction in the following way: (i) First, the query sequence is aligned to the global alignment through a Hidden Markov Model (HMM) profile of the COI protein (Eddy, 1998), followed by a linear search of the reference library. The 100 best hits are selected as a pre-set of "closely related tagged-specimens"; (ii) Second, a Neighbor-Joining tree is reconstructed on this preset plus the query sequence to assess the relationship between the query sequence and its neighboring referenced sequences (Kelly et al., 2007). The query sequence is then assigned to the species name of its nearest-neighboring referenced sequence, whatever the distance between the two sequences. This method is direct and rapid, but its main shortcomings are high prevalence of sampling-dependent accuracy, high rates of false-positive assignments (Koski and Golding, 2001) and the fact that there is no other way to infer the reliability of the query assignment than computing percentages of similarity or genetic distances, two measures that are known to be irrelevant for taxonomic relationship (Ferguson, 2002). The loss of character information is also inherent in distance methods, as computing distances erase all character-based information (DeSalle, 2006). Moreover, as both similarity and distance methods strongly depend on the disparity between intra- and inter-specific variations, incomplete taxonomic sampling (i.e. barcoding gaps) will artificially increase the accuracy of such methods.

Various alternative methods have been proposed to analyse DNA barcode data amongst which we can distinguish four main categories of approaches: (i) similarity approaches, based solely on the similarity between the total DNA barcode sequences or small parts of them (e.g. oligonucleotide motifs, Dasgupta et al., 2005; Little et al., 2007); (ii) classical phylogenetic approaches, using either genetic distances or maximum likelihood / Bayesian algorithms and assuming different mutational models (e.g. Neighbor-Joining, phyML, MrBayes, Elias et al., 2007); (iii) multiple-character based analysis (DeSalle et al., 2005) (vi) pure statistical approaches based on classification algorithms without any biological models or assumptions (CAOS, Sarkar et al., 2002 a, b); and (v) genealogical methods based on the coalescent theory using demo-genetic models and maximum likelihood / Bayesian algorithms (Matz and Nielsen, 2005; Nielsen and Matz, 2006; Abdo and Golding, 2007). The question here is whether it is worthwhile to adopt a biological, populational and/or phylogenetic rationale for DNA barcode sequence analyses or, whether pure statistical approaches are more efficient to assign a query sequence to a species name. Note that character-based methods (either character-based phylogenetics, i.e. not distance-based, or statistical classification) are consistent with the phylogenetic species concept (Goldstein and DeSalle, 2000), whereas distance-based methods are not (Lipscomb et al., 2003). CAOS of Sarkar et al. (2002 a, b) is an example of character-based 
376 analysis, in which the nucleotide sequence is considered as a chain of characters. In the same way, 377 DeSalle et al. (2005) proposed the combination morphological and molecular characters, which has 378 the advantage of bridging the gap between the classical taxonomy and 'molecular-taxonomy' and the 379 DNA barcoding approach.

380 At present, global comparisons between all these approaches are clearly missing. However, 381 few studies have already compared some of these algorithms (Elias et al., 2007, Ross et al., 2008). 382 For example, Austerlitz et al., (Second International Barcode of Life Conference TAIPEI, September 383 2007) compared phylogenetic tree reconstruction with various supervised classification methods 384 (CART and Random Forest, Support Vector Machines and Kernel methods, Breiman et al., 1984) on 385 both simulated and real data sets. Their main conclusions are: (i) maximum likelihood phylogenetic 386 (PhyML, Guindon and Gascuel, 2003) approaches always seem to be more accurate than distance387 based (Neighbor-Joining) phylogenetic inferences; (ii) computation times are much higher for 388 maximum likelihood phylogenetic reconstruction than for statistical classification; and (iii) the 389 accuracy of all the methods strongly depends on sample size and global variability of the taxa. 390 Supervised classification methods outperform phylogenetic analyses only when the reference sample 391 per species is large $(\mathrm{n} \geq 10)$.

Rigorous assignment relevancy depends on our capacity to estimate the probability of a falseassignment event. False species assignments can be due to three types of errors (Nielsen and Matz, 2006): (i) the true species may not be represented in the database; (ii) the random coalescence of lineages in populations and species may not necessarily lead the query sequence to be the most closely related to the true species sequence; (iii) the random process at which mutations arise on lineages may cause the sequence representing another species to be more similar to the query. Population genetics theory, and more specifically coalescent theory, can help to assess the probability of the occurrence of the last two events. Recently, model-based decision theory framework based on the coalescence theory (Matz and Nielsen, 2005; Nielsen and Matz 2006; Abdo and Golding, 2007) has been established, and should lead to greater accuracy in query sequence assignment with an estimation of the degree of confidence with which this assignment can be made. However, the major drawbacks of such model-based decision tools are high computation times and the requirement of large data sets (e.g. more than 10 sequences per species) for enough genetic information to perform accurate analyses. Moreover, the mitochondrial neutrality has recently being 408 put into question (Bazin et al., 2006), which may invalidate inferences using neutral coalescent processes. 
To conclude on the query assignment method, it would be advisable to adopt a sequential

410 investigation. Firstly, to search the complete database with similarity methods thus reducing the total

411 data set to the genus or family of the query sequence. Then, to use statistical classification and/or

412 phylogenetic tools to more precisely assign the query sequence to a given species. If still no obvious

413 assignment emerges, it should then be made using population genetic methods based on coalescence.

414 However, even if the assignment with classification or phylogenetic methods seems unambiguous,

415 coalescent-based methods running on the closest neighbours of the query sequence should give an 416 idea of the degree of uncertainty associated with an identification.

\section{5-2 Delimitation of species}

The second and more controversial objective of DNA barcode analyses is to define clusters of individuals and consider them as species, in other words, to do molecular taxonomy on unidentified taxa. Unlike the approaches mentioned above, clustering is an unsupervised learning problem that involves identifying homogeneous groups in a data set. Beside all the well-justified discussions between taxonomists about the molecular delimitation of species, such a clustering approach is much more complicated than pure assignment to a pre-identified taxonomic group. Three main approaches have been put forward so far.

Hebert et al. (2004b) first proposed the use of a divergence-threshold to delimit species. The underlying idea was that intra-species divergence is lower than inter-species divergence. The standard divergence threshold value advised was of ten times the mean intraspecific variation ('10fold rule') with the reciprocal monophyly. Despite the efficiency of the threshold approach reported for fishes (Ward et al., 2005), crustaceans (Lefebure et al., 2006), North American birds (Hebert et al., 2004b), tropical lepidopterans (Hajibabaei et al., 2006a) and cave-dwelling spiders (Paquin and Hedin, 2004), the use of thresholds in species delineation has been strongly discouraged. Indeed, the divergence-threshold methods lack strong biological support and undoubtedly could not become a universal criterion suited to animal species delineation (Meyer and Paulay, 2005; Hickerson et al., 2006; Wiemer and Fiedler, 2007). By their literature survey of mitochondrial DNA studies on low taxonomic-level animal phylogeny, Funk and Omland (2003) detected species-level paraphyly or polyphyly in $23 \%$ of 2,319 assayed species, demonstrating that NJ-tree analysis will fail to assign query sequences in a significant proportion of cases (Ross et al., 2008). The question is thus to clearly characterize the proportion of non-monophyletic species and the relationship between intra- 
and inter-specific variability in various taxa to globally assess the relevance of such threshold approaches.

The second approach to delimitate species has been developed by Pons et al. (2006) using a mixed model combining a coalescent population model with a Yule model of speciation. Their approach is based on the differences in branching rates at the level of species and populations. Such a model allows them to infer a time of branching regime change, from the coalescent rate to the speciation rate, and to define species as being the clusters for which all individuals are branched inside the coalescent time frame. Even if their approach is currently oversimplified because they consider a unique rate of coalescence (i.e. all population sizes are the same) and a unique shift from population to species processes, it is a promising step that combines the principles of population genetics and those of speciation processes.

The third methodology, which also uses principles of population genetics, is the extension of the coalescent-based models of Matz and Nielsen (2005), Nielsen and Matz (2006) and, Abdo and Golding (2007). This approach has not yet been fully developed but is suggested in the three abovementioned papers. The underlying idea is that maximum likelihood or Bayesian inference, using coalescent models, should help to assess divergence times and/or presence or absence of gene flow between the clusters considered. Estimates of divergence times and gene flow can then be used to infer species status of clusters, based on the biological definition of species. As for the assignment methods, the main drawback of such coalescent-based methods are computation times and large intra-specific sampling requirements.

\section{6- What level of universality can the DNA barcode reach?}

\section{6-1 The choice of the genome region(s)}

The main difficulty of DNA barcoding is to find the ideal gene that discriminates any species in the animal kingdom. Hebert et al. (2003, 2004a,b) argue in favor of the mitochondrial 5' COI region (Folmer et al., 1994), a choice justified by its great resolving-power for birds, lepidopteran and dipteran species discrimination. Ideally, a single pair of universal primers (e.g. Folmer primers, 
476 intra-generic accuracy (e.g. coral reef, Neigel et al., 2007), as illustrated by the primer combinations 477 and cocktails required to obtain DNA barcodes from fish species (Ward et al., 2005; Ivanova et al., 2007), or the primer sets needed to distinguish between primate genera (Lorenz, 2005). The COI amplification does not always ensure the success of the specimen identification. Indeed, the COI-

480 based identification sometimes fails to distinguish closely related animal species, underlining the 481 requirement of nuclear regions (e.g. Cytb and Rhod to identify all teleost fish species, Sevilla et al., 482 2007): the idea of a multi-locus DNA barcoding approach is progressively emerging.

483 The extension of DNA barcoding to other kingdoms is also progressing. The efficiency of COI-based barcoding has been documented for few groups of fungi (e.g. Penicillium sp., Seifert et al., 2007), macroalgae (Rhodophyta, Saunders, 2005) and two ciliophoran protists genera (Paramecium and Tetrahymenas, Barth et al., 2006; Lynn and Strüder-Kypke, 2006; Chantangsi et al., 2007), suggesting that the DNA barcode standardization may be harder to reach than expected. It is now commonly accepted that the universality of the initial COI-based CBOL project is unlikely. Indeed, considering mitochondria solely would not solve problems of differential evolutionary rates among close genera, of inheritance discrepancy, of mtDNA introgression processes and of the intron-size variations that prevent COI-sequence alignment (e.g. fungi, plants). Besides, methods of sequence assignment based on a single-locus will often lack accuracy (Elias et al., 2007). The ineluctable future trend for species identification through DNA barcoding is to develop a multi-locus system, including COI-region or/and independent markers (Rubinoff and Holland, 2005; Dasmahapatra and Mallet 2006; Kress and Erickson, 2007; Smith et al., 2007; Sevilla et al., 2007). Additional molecular markers have already been proposed, among which the nuclear subunit ribosomal RNA genes are promising candidates because of their great abundance in the genome and their relatively conserved flanking regions. Moreover, the use of rRNA allows efficient species distinction (e.g. for amphibians, Vences et al., 2004, 2005; for truffles, El Karkouri et al., 2007), and can sometimes provide classifications into molecular taxonomic units, MOTU (e.g. for nematodes, Floyd et al., 2002; Blaxter et al., 2005).

In higher plants, the mitochondrial genome evolves much more slowly than in animals. The 503 COI-region is thus inappropriate for plant species distinction (Rubinoff et al., 2006). The CBOL 504 plant working group (PWG) agrees that plant barcoding will be multi-locus, with one 'anchor' (i.e. universal across the plant kingdom) and 'identifiers' to distinguish closely related species (Bakker, Second International Barcode of Life Conference TAIPEI, September 2007). Several combinations of DNA regions have been recently proposed (Kress et al., 2005; Chase et al., 2006; Kress and Erickson, 2007; Pennisi, 2007; Lee et al., Second International Barcode of Life Conference TAIPEI, September 2007). At present, there is still no consensus on which candidate markers are the best 
510 plant DNA barcoding region (Pennisi, 2007). The future combination will certainly contain non511 coding intergenic spacers (e.g. $\operatorname{trnH-psbA,~Kress~et~al.,~2005;~Chase~et~al.,~2006;~Kress~and~Erickson,~}$ 512 2007) and plastidial coding sequences (e.g. matK, Chase et al., 2007). Recently, Lahaye et al. (2008) 513 working on a large representative sample ( $>1600$ plants specimens) strongly converged with Chase 514 et al.'s (2007) conclusion, and advocates the matK locus as the best universal 'anchor' for DNA 515 barcoding of plant taxa. However, they also agree with the need for extra loci (i.e. 'identifiers') to 516 resolve lower taxon identification. In addition, Taberlet et al. (2007) focused on the feasibility of 517 barcoding plants from highly degraded DNA that is of interest for ancient DNA studies (e.g. permafrost samples) and other applied fields (e.g. processed food, customs, medicinal plants). They promoted the chloroplast trnL (UAA) intron or a shorter fragment of this intron (the P6 loop, 10-143 bp), which, despite the relatively low resolution, can be amplified with highly conserved primers.

If the prior universality of a single locus and a single primer set remains utopian, the use of a few common loci is still a great advance for future diversity assessments within higher taxa. Steady common features of the DNA barcoding approach will remain, but will certainly evolve in kingdomor even lower taxon- specific technical approaches.

\section{6-2 The challenge: barcoding microscopic biodiversity}

One of the greatest challenges for the Barcode of Life project is to account for the diversity of unicellular life (i.e. archea, bacteria, protists, and unicellular fungi). As a matter of fact, with an evolutionary history dating back to 3.5 billion years, microscopic life $(<1 \mathrm{~mm})$ represents the largest part of biodiversity. Besides, microscopic species are the causal agents of numerous diseases and are keys to the functioning of trophic networks (Chantangsi et al., 2007). In oceans, microbial life is responsible for $98 \%$ of the primary production and the mediation all the biogeochemical cycles (Sogin et al., 2006). One of the striking characteristics of the microbiosphere is the unstable population size over short periods of time, one population can be dominant at a specific time or location, but rare, and thus difficult to survey at another time or location. The low-abundance populations (e.g. rare biosphere) that account for most of the phylogenetic diversity are masked by the dominant populations, leading to an underestimation of the diversity of microbial life (Sogin et al., 2006).

The microbiodiversity DNA barcoding has yet been poorly studied. The emerging community genomics (DeLong et al., 2006) and the metagenomics approaches promise great insights on prokaryote biodiversity and molecular evolution (DeLong, 2004; Tyson et al., 2004; Venter et al., 
544 2004; Tringe et al., 2005; Leclerc et al., 2007). But, for microscopic eukaryotes, the routine use of

545 the metagenomics approach is not technically conceivable and too expensive today, highlighting the interest of DNA barcoding on pooled samples (i.e. where multiple species are present or communities) to assess eukaryotic microbiodiversity (Johnson and Slatkin, 2008).

Exploring the microscopic eukaryotic life diversity can be achieved by the COI-based barcode (Blaxter et al., 2005, Chantangsi et al., 2007; Evans et al., 2007). But as for the macroscopic species, a specific and multi-locus barcoding approach may be required. The 5'-end region (600 bp) of the small ribosomal subunit has already been reported to assign isolates to specific subtypes of the human parasite Blastocyctis hominis (Scicluna et al., 2006) and successfully reached types or species in the deep seas (Sogin et al., 2006).

\section{6-3 Universality of the Barcode Of Life Data system (BOLD)}

The universality of the Barcode of Life mainly resides in the synergic and standard approach for data acquisition and their compilation into BOLD, which is the central connection of the CBOL initiative. The current format for data submission to BOLD is composed of five fields for voucher specimen characterization: (i) the specimen identifier (the catalogue and collection codes, the institution responsible for providing the specimen samples); (ii) the taxonomic status; (iii) the specimen characteristics (sex, life stage, reproduction); (iv) the collection data (collector, collection date and location with GPS coordinates); (v) the DNA barcode sequence (gene name and location, trace file, alignment details, primers used to generate the amplicon). Next to this, pictures of vouchers and the trace of their DNA Barcode must be submitted. All the guidelines are specified on the BOLD website (http://www.barcodinglife.com/docs/boldtutorial.html).

Recently the international sequences depository (NCBI) have accepted to put in place a BARCODE keyword into their search facilities for entries that conform to the minimal CBOL requirements (i.e. traces file, collection location). The BOLD barcode Submission tool associates the 'Barcode submissions' with a further submission to NCBI using the 'My NCBI' user name. Note that for data that satisfies the BARCODE-keyword conditions, the NCBI taxonomy browser gives the direct link to the BOLD taxonomy browser. A keyword related to the concept of "non-COI barcode' may be soon envisaged.

BOLD will provide an increasing amount of DNA barcode records (either COI- or non-COI barcodes) to clearly identify unknown specimens, which will enable accurate query assignments and will facilitate comparison between data obtained in geographically dispersed institutions. Recently, an increasing amount of initiatives for global data recording have been proposed to manage clinical and molecular information about infectious diseases (epiPATH, Amadoz and Gonzales-candelas, 
578 2007), but also to focus on either human pathogenic bacteria (e.g. pathoMIPer, Thiyagarajan et al., 579 2006; pyloriBASE, Ahmed et al. 2007; VectorBase, Lawson et al., 2007; DengueInfo, Schreiber et 580 al., 2007) or on plant pathogens (e.g. PhiBASE, Winnenburg et al., 2006). BOLD could serve as the 581 universal starting point for species identification, which would convey users to refer to specialized 582 databases (e.g. pathogenic strains, disease vector species and endangered species). The CBOL has 583 already initiated the new International Network for the Barcoding of Invasive and Pest Species 584 (INBIPS; www.barcoding.si.edu/INBIPS.htm) that will help to coordinate the collection of barcode 585 data on pest species around the world (Ball and Armstrong, 2006).

\section{7-Conclusion}

After four years, the animal DNA barcoding approach has become less controversial, its relevancy is now supported by numerous successes and by the increasing amount of DNA barcoding projects, among which the barcoding of 500,000 species planned by the iBOL. However, clear limitations arise from the incomplete coverage of the existing diversity, the inherent characteristics of the mitochondrial DNA (evolutionary rate, inheritance, introns, neutrality) and the single-locus initial strategy. With its enlargement to all eukaryote taxa, the Barcode of life project has also evolved to a more flexible framework. The approach reveals to be more complex than the system projected by the CBOL initially. The multi-locus barcoding approach is now commonly accepted, particularly to discriminate between low level taxa and to increase the power of the sequence assignments.

The BOLD data system is central to the DNA barcoding approach. The specificities of BOLD are (i) to assemble standard information on voucher specimens using common description fields (DNA tag, specimen taxonomy, specimens details, collection information, voucher pictures), and, (ii) its dynamic status that allows taxonomic revisions and reassignment of the deposited sequences.

The final point concerning the Barcode of Life project is that, beyond the construction of a standard approach based on the existing taxonomic knowledge, it has enhanced communication between different scientific communities, including taxonomists, phylogeneticists and population geneticists.

609

\section{Acknowledgments}


Frézal, L., Leblois, R. Infection, Genetics and Evolution

611 We thank Kevin Bleakley, Pascale Chesselet, Olivier David, Mark Stevens, Michel Veuille and

612 Thierry Wirth for constructive comments and usefull discussions on the manuscript. L.F. was

613 financially supported by a ATER grant from the Ecole Pratique des Hautes Etudes.

614

615

616

617

618

619

620

621

622

623

624

625

626

627

628

629

630

631

632

633

634

635

636

637

638

639

640

641

642

643

644

645

646

647

648

649

650

651

\section{References}

Abdo, Z., Golding, G.B. 2007. A step toward barcoding life: A model-based, decision-theoretic method to assign genes to preexisting species groups. Syst. Biol. 56, 44-56.

Ahmed, N., Majeed, A.A., Ahmed, I., Hussain, M.A., Alvi, A., Devi, S.M., Rizwan, M., Ranjan, A., Sechi, L.A., Megraud, F. 2007. genoBASE pylori: A genotype search tool and database of the human gastric pathogen Helicobacter pylori. Infect. Genet. Evol. 7, 463-468.

Ahrens, D., Monaghan, M.T., Vogler, A.P. 2007. DNA-based taxonomy for associating adults and larvae in multi-species assemblages of chafers (Coleoptera : Scarabaeidae). Mol. Phylogenet. Evol. 44, 436-449.

Altschul, S.F., Madden, T.L., Schaffer, A.A., Zhang, J., Zhang, Z., Miller, W., Lipman, D.J., 1997. Gapped BLAST and PSI-BLAST: a new generation of protein database search programs. Nucleic Acids Res. 25, 3389-3402.

Amaral, A.R., Sequeira, M., Coelho, M.M. 2007. A first approach to the usefulness of cytochrome c oxidase I barcodes in the identification of closely related delphinid cetacean species. Mar. Freshwater Res. 58, 505-510.

Amadoz, A., Gonzales-candelas, F. 2007. epiPATH: an information system for the storage and management of molecular epidemiology data from infectious pathogens. BMC Infect. Dis. 7, 32. (doi:10.1186/1471-2334-7-32)

Anker, A., Hurt, C., Knowlton, N. 2007. Revision of the Alpheus nuttingi (Schmitt) species complex (Crustacea: Decapoda: Alpheidae), with description of a new species from the tropical eastern Pacific. Zootaxa 1577, 41-60.

Armstrong, K.F., Ball, S.L. 2005. DNA barcodes for biosecurity: invasive species identification. Phil. Trans. R. Soc. B. 360, 1813-1823.

Balakrishnan, R. 2007. Species concepts, species boundaries and species identification: a view from the tropics. Syst. Biol. 54(4):689-693.

Ball, S.L., Hebert, P.D.N., Burian, S.K., Webb, J.M. 2005. Biological identifications of mayflies (Ephemeroptera) using DNA barcodes. J. North Am. Benthol. Soc. 24, 508-524.

Ball, S.L., Armstrong, K.F. 2006. DNA barcodes for insect pest identification: a test case with tussock moths (Lepidoptera: Lymantriidae). Can. J. For. Res. 36: 337-350.

Barth, D., Krenek, S., Fokin, S.I., Berendonk, T.U. 2006. Intraspecific genetic variation in Paramecium revealed by mitochondrial cytochrome c oxidase 1 sequences. J. Eukaryot. Microbiol., 53: 20-25.

Bazin, E., Glémin, S., Galtier, N. 2006. Population size does mitochondrial genetic in animals. Science 312, 570-572.

Berkov, A., Feinstein, J., Small, J., Nkamany, M. 2007. Yeasts isolated from neotropical woodboring beetles in SE Peru. Biotropica 39, 530-538. 
Frézal, L., Leblois, R. Infection, Genetics and Evolution

Besansky, N.J., Severson, D.W., Ferdig, M.T. 2003. DNA barcoding of parasites and invertebrate disease vectors: what you don't know can hurt you. Trends Parasitol. 19, 545-546.

Blaxter, M., Mann, J., Chapman, T., Thomas, F., Whitton, C., Floyd, R., Abebe, E. 2005. Defining operational taxonomic units using DNA barcode data. Phil. Trans. Roy. Soc. Lond. B 360, 1935-1943.

Blaxter, M. 2006. Will DNA barcoding advance efforts to conserve biodiversity more efficiently than traditional taxonomic methods? Front. Ecol. Environ. 5, 269-270.

Bourlat, S.J., Nakano, H., Akerman, M., Telford, M.J., Thorndyke M.C., and Obst M. 2008. Feeding ecology of Xenoturbella bocki (phylum Xenoturbellida) revealed by genetic barcoding Mol. Ecol. Resources 8, 18-22

Breiman, L., Friedman, J.H., Olshen, R.A., Stone, C.J., 1984. Classification and Regression Trees. Wadsworth, Belmont.

Bucklin, A., Wiebe, P.H., Smolenack, S.B., Copley, N.J., Beaudet, J.G., Bonner, K.G., FarberLorda, J., Pierson, J.J. 2007. DNA barcodes for species identification of euphausiids (Euphausiacea, Crustacea). J. Plankton Res. 29, 483-493.

Carlini, D.B., Kunkle, L.K., Vecchione, M. 2006. A molecular systematic evaluation of the squid genus Illex (Cephalopoda: Ommastrephidae) in the North Atlantic Ocean and Mediterranean Sea. Mol. Phylogenet. Evol. 41, 496-502.

Caterino, M.S., Tishechkin, A.K. 2006. DNA identification and morphological description of the first confirmed larvae of Hetaeriinae (Coleoptera : Histeridae). Syst. Entomol. 31, 405-418.

Chantangsi, C., Lynn, D.H., Brandl, M.T., Cole, J.C., Hetrick, N., Ikonomi, P. 2007. Barcoding ciliates: a comprehensive study of 75 isolates of the genus Tetrahymena. Int. J. Syst. Evol. Microbiol. 57, 2412-2425.

Chase, M.W., Salamin, N., Wilkinson, M., Dunwell, J.M., Kesanakurthi, R.P., Haidar, N., Savolainen, V. 2005. Land plants and DNA barcodes: short-term and long-term goals. Phil. Trans. R. Soc. B 360, 1889-1895

Chase, M.W., Cowan, R.S., Hollingsworth, P.M., van den Berg, C., Madrinan, S., Petersen, G., Seberg, O., Jorgsensen, T., Cameron, K.M., Carine, M., Pedersen, N., Hedderson, T.A.J., Conrad, F., Salazar, G.A., Richardson, J.E., Hollingsworth, M.L., Barraclough, T.G., Kelly, L., Wilkinson, M. 2007. A proposal for a standardised protocol to barcode all land plants. Taxon 56, 295-299.

Collura, R.V., Auerbach, M.R., Stewart, C-B. 1996. A quick, direct method that can differentiate expressed mitochondrial genes from their nuclear pseudogenes. Curr. Biol. 6 (10), 1337-1339.

Costa, F.O., deWaard, J.R., Boutillier, J., Ratnasingham, S., Dooh, R.T., Hajibabaei, M., Hebert, P.D.N. 2007. Biological identifications through DNA barcodes: the case of the Crustacea. Can. J. Fish. Aquat. Sci. 64, 272-295.

Dasmahapatra, K.K., Mallet, J. 2006. DNA barcodes: recent successes and future prospects. Heredity 97, 254-255.

DasGupa, B., Konwar, K.M., Mandoiu, I.I., Shvartsman, A.A. 2005. DNA-BAR: distinguisher selection for DNA barcoding. Bioinformatics 21, 3424-3426.

Dayrat, B. 2005. Towards integrative taxonomy. Biol. J. Linn. Soc. 85, 407-415.

DeLong, E.F. 2004. Microbial population genomics and ecology: the road ahead Environmental Microbiology 6 (9), 875-878. (doi:10.1111/j.1462-2920.2004.00668.x) 
DeLong, E.F., Preston, C.M., Mincer, T. , Rich, V., Hallam, S.J., Frigaard, N.-U., Martinez, A., Sullivan, M.B., Edwards, R., Brito, B.R., Chisholm, S.W., Karl, D.M. 2006. Community genomics among stratified microbial assemblages in the ocean's interior. Science 311, 5760: 496-503.

DeSalle, R., Egan, M.G., Siddall, M. 2005. The unholy trinity: taxonomy, species delimitation and DNA barcoding. Phil. Trans. R. Soc. B 360, 1905-1916.

DeSalle, R. 2006. Species discovery versus species identification in DNA barcoding efforts: Response to Rubinoff. Cons. Biol. 20, 1545-1547.

Ebach, M.C., Holdrege, C. 2005. DNA barcoding is no substitute for taxonomy. Nature 434, 697697.

Eddy, S.R. 1998. Profile hidden Markov models. Bioinformatics 14, 755-763.

Elias, M., Hill, R.I., Willmott, K.R., Dasmahapatra, K.K., Andrew V.Z. Brower, A.V.Z., Mallet, J., Chris D., Jiggins, C.D. 2007 Limited performance of DNA barcoding in a diverse community of tropical butterflies. Proc. Roy. Soc. Lond. B 274, 2881-2889.

El Karkouri, K., Murat, C., Zampieri, E., 2007. Identification of internal transcribed Spacer sequence motifs in truffles: a first step toward their DNA barcoding. Appl. Environ. Microbiol. 73 (16), 5320-5330.

Erpenbeck, D., Hooper, J.N.A., Worheide, G. 2006. CO1 phylogenies in diploblasts and the 'Barcoding of Life' - are we sequencing a suboptimal partition? Mol. Ecol. Notes 6, 550-553.

Evans, K.M., Wortley, A.H., Mann, D.G. 2007. An assessment of potential diatom "barcode" genes (cox1, rbcL, 18S and ITS rDNA) and their effectiveness in determining relationships in Sellaphora (Bacillariophyta). Protist 158, 349-364.

Ferguson, J.W.H. 2002. On the use of genetic divergence for identifying species. Biol. J. Linn. Soc. 75, C509-C516.

Fitzhugh, K. 2006. DNA Barcoding: An Instance of Technology-driven Science? BioScience 56(6), 462-463.

Folmer, O., Black, M., Hoeh, W., Lutz, R., Vrijenhoek, R. 1994. DNA primers for amplification of mitochondrial cytochrome c oxidase subunit I from diverse metazoan invertebrates. Mol. Mar. Biol. Biotech. 3, 294-299.

Floyd, R., Abebe, E., Papert, A., Blaxter, M. 2002. Molecular barcodes for soil nematode identification. Mol. Ecol. 11, 839-850.

Funk, D.J., Helbling, L., Wernegreen, J.J., Moran, N.A. 2000. Intraspecific phylogenetic congruence among multiple symbiont genomes. Proc. R. Soc. B. 267, 2517-2521.

Funk, DJ., Omland, K.E. 2003. Species-level paraphyly and polyphyly: frequency, causes, and consequences, with insights from animal mitochondrial DNA. Annu. Rev. Ecol. Evol. Syst. 34, $397-423$

Guindon, S., Gascuel, O. 2003 A simple, fast, and accurate algorithm to estimate large phylogenies by maximum likelihood. Syst. Biol. 52, 696-704.

Goldstein, P.Z., DeSalle, R. 2000. Phylogenetic species, nested hierarchies, and character fixation. Cladistics 16, 364-384.

Gomez, A., Wright, P.J., Lunt, D.H., Cancino, J.M., Carvalho, G.R., Hughes, R.N. 2007. Mating trials validate the use of DNA barcoding to reveal cryptic speciation of a marine bryozoan taxon. Proc. Roy. Soc. Lond. B. 274, 199-207. 
Frézal, L., Leblois, R. Infection, Genetics and Evolution

Greenstone, M.H., Rowley, D.L., Heimbach, U., Lundgren, J.G., Pfannenstiel, R.S., Rehner, S.A. 2005. Barcoding generalist predators by polymerase chain reaction: carabids and spiders. Mol. Ecol. 14, 3247-3266.

Gregory, T.R., 2005. DNA barcoding does not compete with taxonomy. Nature 434, 1067-1067.

Gressel, J., Ehrlich, G. 2002. Universal inheritable barcodes for identifying organisms. Trends Plant Sci. 7 (12), 542-544.

Hajibabaei, M., Janzen, D.H., Burns, J.M., Hallwachs, W., Hebert, P.D.N. 2006a. DNA barcodes distinguish species of tropical Lepidoptera. Proc. Natl. Acad. Sci. U.S.A. 103, 968-971.

Hajibabaei, M., Singer, G.A.C., Hickey, D.A. 2006b. Benchmarking DNA barcodes: an assessment using available primate sequences. Genome 49, 851-854.

Hajibabaei, M., Smith, M.A., Janzen, D.H., Rodriguez, J.J., Whitfield, J.B., Hebert, P.D.N. 2006c. A minimalist barcode can identify a specimen whose DNA is degraded. Mol. Ecol. Notes 6, 959964.

Hajibabaei, M., Singer, G.A.C., Clare, E.L., Hebert, P.D.N. 2007a. Design and applicability of DNA arrays and DNA barcodes in biodiversity monitoring. BMC Biol. 5 (24). (doi:10.1186/17417007-5-24)

Hajibabaei, M., Singer, G.A.C., Hebert, P.D.N., Hickey, D.A. 2007b. DNA barcoding: how it complements taxonomy, molecular phylogenetics and population genetics. Trends Genet. 23, 167-172.

Handfield, D., Handfield, L. 2006. A new species of Plusia (Lepidoptera : Noctuidae) from North America. Can. Entomol. 138, 853-859.

Hebert, P.D.N., Ratnasingham, S., deWaard, J.R. 2003. Barcoding animal life: cytochrome c oxidase subunit 1 divergences among closely related species. Proc. Roy. Soc. Lond. B. 270, S96-S99.

Hebert, P.D.N., Penton, E.H., Burns, J.M., Janzen, D.H., Hallwachs, W. 2004a. Ten species in one: DNA barcoding reveals cryptic species in the neotropical skipper butterfly Astraptes fulgerator. Proc. Natl. Acad. Sci. U.S.A. 101, 14812-14817.

Hebert, P.D.N., Stoeckle, M.Y., Zemlak, T.S., Francis, C.M. 2004b. Identification of birds through DNA barcodes. Plos Biol. 2, 1657-1663.

Hebert, P.D.N., Barrett, R.D.H. 2005a. Reply to the comment by L. Prendini on "Identifying spiders through DNA barcodes". Can. J. Zool. 83, 505-506.

Hebert, P.D.N., Gregory, T.R. 2005b. The promise of DNA barcoding for taxonomy. Syst. Biol. 54, 852-859.

Hickerson, M.J., Meyer, C.P., Moritz, C. 2006. DNA barcoding will often fail to discover new animal species over broad parameter space. Syst. Biol. 55, 729-739.

Hogg, I.D., Hebert, P.D.N. 2004. Biological identification of springtails (Hexapoda : Collembola) from the Canadian Arctic, using mitochondrial DNA barcodes. Can. J. Zool. 82, 749-754.

Huang, J., Qin Xu, Q., Sun, Z.J., Tang, G.L., Su, Z.Y. 2007. Identifying earthworms through DNA barcodes. Pedobiologia 51, 301-309.

Hudson, M.E., 2007. Sequencing breakthroughs for genomic ecology and evolutionary biology. Mol. Ecol. Notes (doi:10.1111/j.1471-8286.2007.02019)

Hulcr, J., Miller, S.E., Setliff, G.P., Darrow, K., Mueller, N.D., Hebert, P.D.N., Weiblen, G.D. 2007. DNA barcoding confirms polyphagy in a generalist moth, Homona mermerodes (Lepidoptera: Tortricidae). Mol. Ecol. Notes 7, 549-557. 
Hunter, S.J., Goodall, T.I., Walsh, K.A., Owen, R., Day, J.C. 2007. Nondestructive DNA extraction from blackflies (Diptera: Simuliidae): retaining voucher specimens for DNA barcoding projects. Mol. Ecol. Notes (doi: 10.1111/j.1471-8286.2007.01879)

Hurst, G.D.D., Jiggins, F.M., von der Schulenburg, J.H.G., Bertrand, D., West, S.A., Goriacheva, I.I., Zakharov, I.A., Werren, J.H,. Stouthamer, R., Majerus, M.E.N. 1999. Male-killing Wolbachia in two species of insect. Proc. Roy. Soc. B. 266, 735-740. (doi:10.1098/rspb.1999.0698.)

Hurst, G.D., Jiggins, F.M. 2005. Problems with mitochondrial DNA as a marker in population, phylogeographic and phylogenetic studies: the effects of inherited symbionts. Proc. Biol. Sci. $272,1525-1534$.

Ivanova, N.V., Zemlak, T.S., Hanner, R.H., Hebert, P.D.N. 2007. Universal primer cocktails for fish DNA barcoding. Mol. Ecol. Notes 7, 544-548.

Jaklitsch, W.M., Komon, M., Kubicek, C.P., Druzhinina, I.S. 2006. Hypocrea crystalligena sp nov., a common European species with a white-spored Trichoderma anamorph. Mycologia 98, 499513.

Johnson, P.L.F., Slatkin, M. 2006. Inference of population genetic parameters in metagenomics: A clean look at messy data. Genome Res. 16: 1320-1327

Kelly, R.P., Sarkar, I.N., Eernisse, D.J., DeSalle, R. 2007. DNA barcoding using chitons (genus Mopalia). Mol. Ecol. Notes 7, 177-183.

Kerr, K.C.R., Stoeckle, M.Y., Dove, C.J., Weigt, L.A., Francis, C.M., Hebert, P.D.N. 2007. Comprehensive DNA barcode coverage of North American birds. Mol. Ecol. Notes 7, 535543.

Koski, L.B., Golding, G.B. 2001. The closest blast hit is often not the nearest neighbor. J. Mol. Ecol. $52,540-542$.

Kress, W.J., Wurdack, K.J., Zimmer, E.A., Weigt, L.A., Janzen, D.H. 2005. Use of DNA barcodes to identify flowering plants. Proc. Natl. Acad. Sci. U.S.A. 102, 8369-8374.

Kress,W.J., Erickson, D.L. 2007. A two-locus global DNA barcode for land plants: the coding $r b c L$ gene complements the non-coding trnHpsbA spacer region. Plos one 2(6): e508. (doi:10.1371/journal.pone.0000508)

Kumar, N.P., Rajavel, A.R., Natarajan, R., Jambulingam, P. 2007. DNA barcodes can distinguish species of Indian mosquitoes (Diptera : Culicidae). J. Med. Entomol. 44, 1-7.

Lahaye, R., van der Bank, M., Bogarin, D., Warner, J., Pupulin, F., Gigot, G., Maurin, O., Duthoit, Barraclough, T.G., and Savolainen, V. 2008. DNA barcoding the floras of biodiversity hotspots. Proc. Natl. Acad. Sci. U.S.A. 105 (8), 2923-2928.

Lane, C.E., Lindstrom, S.C., Saunders, G.W. 2007. A molecular assessment of northeast Pacific Alaria species (Laminariales, Phaeophyceae) with reference to the utility of DNA barcoding. Mol. Phylogenet. Evol. 44, 634-648.

Lawson, D., Arensburger, P., Atkinson, P., Besansky, N.J., Bruggner, R.V., Butler, R., Campbell, K.S., Christophides, G.K., Christley, S., Dialynas, E., Emmert, D., Hammond,M., Hill, C.A., Kennedy, R.C., Lobo, N.F., MacCallum, M.R., Madey, G., Megy, K., Redmond, S., Russo, S., Severson, D.W., Stinson, E.O., Topalis, P., Zdobnov, E.M., Birney, E., Gelbart, W.M., Kafatos, F.C., Louis, C., Collins, F.H. 2007. VectorBase: a home for invertebrate vectors of human pathogens. Nucleic Acids Res. 35, D503-505. 
Lefebure, T., Douady, C.J., Gouy, M., Gibert, J. 2006. Relationship between morphological taxonomy and molecular divergence within Crustacea: Proposal of a molecular threshold to help species delimitation. Mol. Phylogenet. Evol. 40, 435-447.

Leclerc, M., Juste, C., Marteau, P., Nalin R., Blottiere H., Dore, J. 2007. Intestinal metagenomics and nutrition. Annals Nutri. Metabol. 51 (13) (13 Suppl. 1).

Lipscomb, D., Platnick, N., Wheeler, Q. 2003. The intellectual content of taxonomy: a comment on DNA taxonomy. Trends Ecol. Evol. 18, 65-66.

Litaker, R.W., Vandersea, M.W., Kibler, S.R., Reece, K.S., Stokes, N.A., Lutzoni, F.M., Yonish, B.A., West, M.A., Black, M.N.D., Tester, P.A. 2007. Recognizing dinoflagellate species using ITS rDNA sequences. J. Phycol. 43, 344-355.

Little, D.P., Stevenson, D.W. 2007. A comparison of algorithms for the identification of specimens using DNA barcodes: examples from gymnosperms. Cladistics 23, 1-21.

Lorenz, J.G., Jackson, W.E., Beck, J.C., Hanner, R. 2005. The problems and promise of DNA barcodes for species diagnosis of primate biomaterials. Phil. Trans. R. Soc. B 360, 1869-1877.

Lynn, D.H., Struder-Kypke, M.C. 2006. Species of Tetrahymena identical by small subunit rRNA gene sequences are discriminated by mitochondrial cytochrome c oxidase I gene sequences. J. Eukaryot. Microbiol. 53, 385-387.

Maiden, M.C.J., Bygraves, J.A., Feil, E., Morelli, G., Russell, J.E., Urwin, R. Zhang, Q., Zhou, J., Zurth, K., Caugant, D.A., Feavers, I.M., Achtman, M., Spratt, B.G. 1996. Multilocus sequence typing: A portable approach to the identification of clones within populations of pathogenic microorganisms. Proc. Natl. Acad. Sci. U.S.A. 95 (6), 3140-3145.

Matz, M.V., Nielsen, R. 2005. A likelihood ratio test for species membership based on DNA sequence data. Phil. Trans. R. Soc. B 360, 1969-1974.

Meyer, C.P., Paulay, G. 2005. DNA barcoding: Error rates based on comprehensive sampling. Plos Biology 3, 2229-2238.

Miller, S.E. 2007. DNA barcoding and the renaissance of taxonomy. Proc. Natl. Acad. Sci. U.S.A. $104,4775-4776$.

Min, X.J., Hickey, D.A. 2007. Assessing the effect of varying sequence length on DNA barcoding of fungi. Mol. Ecol. Notes 7, 365-373.

Neigel, J., Domingo, A., Stake, J. 2007. DNA barcoding as a tool for coral reef conservation. Coral Reefs 26, 487-499.

Nielsen, R., Matz, M. 2006. Statistical approaches for DNA barcoding. Syst. Biol. 55, 162-169.

Page, T.J., Choy, S.C., Hughes, J.M. 2005. The taxonomic feedback loop: symbiosis of morphology and molecules. Biol. Lett.1, 139-142.

Paquin, P., Hedin, M. 2004. The power and perils of "molecular taxonomy": a case study of eyeless and endangered Cicurina (Araneae: Dictynidae) from Texas caves. Mol. Ecol. 13: 3239-3255.

Passmore, A.J., Jarman, S.N., Swadling, K.M., Kawaguchi, S., McMinn, A., Nicol, S. 2006. DNA as a Dietary Biomarker in Antarctic Krill, Euphausia superba. Mar. Biotech. 8, 686-696.

Pennisi, E. 2007 Wanted: A Barocde for Plants. Science 318(2): 190-191.

Pegg, G.G., Sinclair, B., Briskey, L., Aspden, W.J. 2006. MtDNA barcode identification of fish larvae in the southern Great Barrier Reef, Australia. Scientia Marina 70, 7-12. 
Pfenninger, M., Nowak, C., Kley, C., Steinke, D. Streit, B. 2007. Utility of DNA taxonomy and barcoding for the inference of larval community structure in morphologically cryptic Chironomus (Diptera) species. Mol. Ecol. 16, 1957-1968.

Pons, T., Gonzalez, B., Ceciliani, F., Galizzi, A. 2006. FlgM anti-sigma factors: identification of novel members of the family, evolutionary analysis, homology modeling, and analysis of sequence-structure-function relationships. J. Mol. Model. 12 (6), 973-983.

Pook, C.E., McEwing, R. 2005. Mitochondrial DNA sequences from dried snake venom: a DNA barcoding approach to the identification of venom samples. Toxicon 46, 711-715.

Rastogi, G., Dharne, M.S., Walujkar, S., Kumar, A., Patole, M.S., Shouche, Y.S. 2007. Species identification and authentication of tissues of animal origin using mitochondrial and nuclear markers. Meat Sci. 76, 666-674.

Ratnasingham, S., Hebert, P.D.N. 2007. BOLD: The Barcode of Life Data System (www.barcodinglife.org). Mol. Ecol. Notes 7, 355-364.

Remigio, E.A., Hebert, PDN. 2003. Testing the utility of partial COI sequences for phylogenetic estimates of Gastropod relationships. Mol. Phylogenet. Evol. 29, 641-647.

Richly, E., Leister, D. 2004. NUMTs in sequenced eukaryotic genomes. Mol. Biol. Evol. 21, 10811084.

Robba, L., Russell, S.J., Barker, G.L., Brodie, J. 2006. Assessing the use of the mitochondrial cox1 marker for use in DNA barcoding of red algae (Rhodophyta). Am. J. Bot. 93, 1101-1108.

Ross, H.A., Murugan, S., Li, W.L.S. 2008. Testing the reliability of genetic methods of species identification via simulation. Systematic Biology 57:216-230.

Rot, C., Goldfarb, I., Ilan, M., Huchon, D. 2006 Putative cross-kingdom horizontal gene transfer in sponge (Porifera) mitochondria. BMC Evol. Biol. 6(71). (doi:10.1186/1471-2148-6-71)

Rowley, D.L., Coddington, J., Norrbom, A., Ochoa, R., Vandenberg, N., Greenstone, M.H. 2007. Vouchering specimens for documenting arthropod barcodes: a non-destructive method for DNA extraction. Mol. Ecol. Notes 7, 915-924.

Rubinoff, D., Holland, B.S. 2005. Between two extremes: mitochondrial DNA is neither the panacea nor the nemesis of phylogenetic and taxonomic inference. Syst. Biol. 54,92-961.

Rubinoff, D. 2006a. Utility of mitochondrial DNA barcodes in species conservation. Cons. Biol. 20, 1026-1033.

Rubinoff, D. 2006b. DNA barcoding evolves into the familiar. Cons. Biol. 20, 1548-1549.

Rubinoff, D., Cameron, S. Will, K. 2006. Are plant DNA barcodes a search for the Holy Grail? Trends Ecol. Evol. 21, 1-2.

Rusch, D.B., Halpern, A.L., Sutton, G., Heidelberg, K.B., Williamson, S., Yooseph, S., Wu, D., Eisen, J.A., Hoffman, J.M., Remington, K., Beeson, K., Tran, B., Smith, H., Baden-Tillson,H., Stewart, C., Thorpe, J., Freeman, J., Andrews-Pfannkoch, C., Venter, J.E. , Li, K., Kravitz, S., Heidelberg, J.F., Utterback, T., Rogers, Y-H., Falcon, L.I., Souza, V., Bonilla-Rosso, G., Eguiarte, L.E., Karl, D.M., Sathyendranath, S., Platt, T., Bermingham, E., Gallardo, V., Tamayo-Castillo,G., Ferrari, M.R., Strausberg, R.L., Nealson, K., Friedman, R., Frazier, M., Venter, J.C. 2007. The Sorcerer II Global Ocean Sampling expedition: Northwest Atlantic through eastern tropical Pacific. Plos Biol. 5(3) e77, 398-431. (doi:10.1371/journal.pbio.0050077)

Sarkar, I.N., Joseph, W.T., Paul, J.P., David, H.F., Bernd, S., Rob., D. 2002a. An automated phylogenetic key for classifying homeoboxes. Mol. Phylogenet. Evol. 24, 388-399. 
Frézal, L., Leblois, R. Infection, Genetics and Evolution

909

910

911

912

913

914

915

916

917

918

919

920

921

922

923

924

925

926

927

928

929

930

931

932

933

934

935

936

937

938

939

940

941

942

943

944

945

946

947

948

949

950

951

952

Sarkar I.N., Paul, J.P., Bael, T.E., Stanley, S.E., Siddall, M., DeSalle, R., David, H.F. $2002 b$. Characteristic attributes in cancer microarrays. J. Biomed. Info. 35, 111-122.

Saunders, G.W. 2005. Applying DNA barcoding to red macroalgae: a preliminary appraisal holds promise for future applications. Phil. Trans. R. Soc. Lond. B 360, 1879-1888.

Schindel, D.E., Miller, S.E. 2005. DNA barcoding a useful tool for taxonomists. Nature 435, 17-17.

Schreiber, M.J., Ong, S.H., Holland, R.C.G., Hibberd, M.L., Vasudevan, S.G., Mitchell, W.P., Holmes, E.C. 2007. DengueInfo: A web portal to dengue information resources. Infect. Genet. Evol. 540-541.

Scicluna, S.M., Tawari, B., Clark, C.G. 2006. DNA barcoding of Blastopystis. Protist 157, 77-85.

Seifert, K.A., Samson, R.A., Dewaard, J.R., Houbraken, J., Levesque, C.A., Moncalvo, J.M., LouisSeize, G., Hebert, P.D.N. 2007. Prospects for fungus identification using C01 DNA barcodes, with Penicillium as a test case. Proc. Natl. Acad. Sci. U.S.A. 104, 3901-3906.

Sevilla, R.G., Diez, A., Noren, M., Mouchel, O., Jerome, M., Verrez-Bagnis, V., van Pelt, H., FavreKrey, L., Krey, G., Bautista, J.M. 2007. Primers and polymerase chain reaction conditions for DNA barcoding teleost fish based on the mitochondrial cytochrome $b$ and nuclear rhodopsin genes. Mol. Ecol. Notes 7, 730-734.

Shenoy, B.D., Jeewon, R., Hyde, K.A. 2007. Impact of DNA sequence-data on the taxonomy of anamorphic fungi. Fungal Div. 26, 1-54.

Smith, M.A., Fisher, B.L. Hebert, P.D.N. 2005. DNA barcoding for effective biodiversity assessment of a hyperdiverse arthropod group: the ants of Madagascar. Phil. Trans. R. Soc. B $360,1825-1834$.

Smith, G.F., Roux, J.P., Tolley, K. Conrad, F. 2006a. Taxonomy and barcoding: conflict or companions? S. Af. J. Sci. 102, 517-518.

Smith, M.A., Woodley, N.E., Janzen, D.H., Hallwachs, W., Hebert, P.D.N. 2006b. DNA barcodes reveal cryptic host-specificity within the presumed polyphagous members of a genus of parasitoid flies (Diptera : Tachinidae). Proc. Natl. Acad. Sci. U.S.A. 103, 3657-3662.

Smith, M.A., Wood, D.M., Janzen, D.H., Hallwachs, W., Hebert, P.D.N. 2007. DNA barcodes affirm that 16 species of apparently generalist tropical parasitoid flies (Diptera, Tachinidae) are not all generalists. Proc. Natl. Acad. Sci. U.S.A. 104(12), 4967-4972.

Sogin, M.L., Morrison, H.G., Huber, J.A., Welch, D.M., Huse, S.M., Neal, P.R., Arrieta, J.M., Herndl, G.J. 2006. Microbial diversity in the deep sea and the underexplored "rare biosphere". Proc. Natl. Acad. Sci. U.S.A. 103, 12115-12120.

Strugnell, J.M., Lindgren, A.R. 2007. A barcode of life database for the Cephalopoda? Considerations and concerns. Rev. Fish Biol. Fish. 17, 337-344.

Sugita, T., Nishikawa, A., Shinoda, T. 1998. Identification of trichosporon asahii by PCR based on sequences of the internal transcribed spacer regions. J. of clinical microbiol. 2742-2744.

Summerbell, R.C., Levesque, C.A., Seifert, K.A., Bovers, M., Fell, J.W., Diaz, M.R., Boekhout, T., de Hoog, G.S., Stalpers, J., Crous, P.W. 2005. Microcoding: the second step in DNA barcoding. Phil. Trans. R. Soc. B 360, 1897-1903.

Taberlet, P., Coissac, E., Pompanon, F., Gielly, L., Miquel, C., Valentini, A., Vermat, T., Corthier, G., Brochmann, C., Willerslev, E. 2007. Power and limitations of the chloroplast trnL (UAA) intron for plant DNA barcoding. Nucleic Acids Res. 35 (3), e14.

Tavares, E.S., and Baker, A.J. 2008. Single mitochondrial gene barcodes reliably identify sisterspecies in diverse clades of birds. BMC Evol. Biol. 8: 81 
953

954

955

956

957

958

959

960

961

962

963

964

965

966

967

968

969

970

971

972

973

974

975

976

977

978

979

980

981

982

983

984

985

986

987

988

989

990

991

992

993

994

995

Terranova, M.S., Brutto, S.L., M. Arculeo, M., Mitton, J.B. 2007. A mitochondrial phylogeography of Brachidontes variabilis (Bivalvia: Mytilidae) reveals three cryptic species J. Zool. Syst. Evol. Res. 45(4), 289-298.

Teletchea, F., Bernillon, J., Duffraisse, M., Laudet, V., Hänni, C. 2008 Molecular identification of vertebrate species by oligonucleotide microarray in food and forensic samples. J. of App. Ecol.( doi: 10.1111/j.1365-2664.2007.01415.x)

Thalmann, O., Hebler, J., Poinar, H.N., Paabo, S., Vigilant, L. 2004. Unreliable mtDNA data due to nuclear insertions: a cautionary tale from analysis of humans and other great apes. Mol. Ecol. $13,321-335$.

Thiyagarajan, S., Karhanek, M., Akhras, M., Davis, R.W., Pourmand, N. 2006. PathogenMIPer: a tool for the design of molecular inversion probes to detect multiple pathogens. BMC Bioinform. 7. (doi:10.1186/1471-2105-7-500).

Tringe, S.G., von Mering, C., Kobayashi, A., Salamov, A.A., Chen, K., Chang, H.W., Podar, M., Short, J.M., Mathur, E.J., Detter, J.C., Bork, P., Hugenholtz, P., Rubin, E.M. 2005. Comparative metagenomics of microbial communities. Science 308, 554-557.

Tyson, G.W., Chapman, J., Hugenholtz, P., Allen, E.E., Ram, R.J., Richardson, P.M., Solovyev, V.V., Rubin, E.M., Rokhsar, D.S., Banfield, J.F. 2004. Community structure and metabolism through reconstruction of microbial genomes from the environment. Nature 428, 37-43.

Van Velzen, R., Freek, T., Bakker, L., Van Loon, J.J.A. 2007. DNA barcoding reveals hidden species diversity in Cymothoe (Nymphalidae). Proc. Neth. Entomol. Soc. Meet. 18, 95-103.

Vences, M., Thomas, M., Van der Meijden, A., Chiari, Y., Vieites, D.R. 2004. Performance of 16S rRNA in DNA barcoding of amphibians. Integr. Comp. Biol. 44, 657-657.

Vences, M., Thomas, M., Bonett, R.M., Vieites, D.R. 2005. Deciphering amphibian diversity through DNA barcoding: chances and challenges. Phil. Trans. Roy. Soc. Lond. B 360, 18591868 .

Venter JC, Remington K, Heidelberg JF, Halpern AL, Rusch D, Eisen JA, Wu D, Paulsen I, Nelson KE, Nelson W, Fouts DE, Levy S, Knap AH, Lomas MW, Nealson K, White O, Peterson J, Hoffman J, Parsons R, Baden-Tillson H, Pfannkoch C, Rogers Y, Smith HO: Environmental genome shotgun sequencing of the sargasso sea. Science 2004 304, 66-74.

Vogler, A.P., Monaghan, M.T. 2007. Recent advances in DNA taxonomy. J. Zool. Syst. Evol. Res. 45(1), 1-10.

Ward, R.D., Zemlak, T.S., Innes, B.H., Last, P.R., Hebert, P.D.N. 2005. DNA barcoding Australia's fish species. Phil. Trans. Roy. Soc. Lond. B. 360, 1847-1857.

Webb, K.E., Barnes, D.K.A., Clark, M.S., Bowden, D.A. 2006. DNA barcoding: A molecular tool to identify Antarctic marine larvae. Deep-Sea Res. Part II 53, 1053-1060.

Weeks, A.R., Turelli, M., Harcombe, W.R., Reynolds, K.T., Hoffmann, A.A. 2007. From parasite to mutualist: Rapid evolution of Wolbachia in natural populations of Drosophila. Plos Biol 5(5), e114. (doi:10.1371/journal.pbio.0050114)

Whitworth, T.L., Dawson, R.D., Magalon, H., Baudry, E. 2007. DNA barcoding cannot reliably identify species of the blowfly genus Protocalliphora (Diptera : Calliphoridae). Proc. Roy. Soc. Lond. B 274, 1731-1739.

Wiemer, M., Fiedler, K. 2007. Does the DNA barcoding gap exist? - a case study in blue butterflies (Lepidoptera: Lycaenidae). Front. Zool. 4(8) (doi:10.1186/1742-9994-4-8). 
Winnenburg, R., Baldwin1, T.K., Urban1, M., Rawlings, C. Kohler, J., Hammond-Kosack, K.E. 2006. Nucleic Acids Res. 34, D459-464 (doi:10.1093/nar/gkj047).

Willams, S.T., Knowlton, N. 2001. Mitochondrial pseudogenes are pervasive and often insidious in the snapping shrimp genus Alpheus. Mol. Biol. Evol. 18,1484-1493

Wilson, O.E. 2004. The encyclopedia of life. Trends Ecol. Evol. 18(2), 77-80.

Wirth, T., Le Guellec, R., Veuille, M. 1999. Directional Substitution and Evolution of Nucleotide Content in the Cytochrome Oxidase II Gene in Earwigs (Dermapteran Insects). Mol. Biol. Evol. 16(12), 1645-1653.

Wirth, T., Falush, D., Lan, R., Colles, F., Mensa, P., Wieler, L.H., Karch, H., Reeves, P.R., Maiden, M.C.J., Ochman, H., Achtman, M. 2006. Sex and virulence in Escherichia coli: an evolutionary perspective. Mol. Microbiol. 60 (5), 1136-1151.

Woese, C.R. 1996. Phylogenetic trees: whither microbiology? Current biol. 1060-1063.

Xiao, M., Gordon, M.P., Phong, A., Ha, C., Chan, T.F., Cai, D.M., Selvin, P.R., Kwok, P.Y. 2007. Determination of haplotypes from single DNA molecules: A method for single-molecule barcoding. Hum. Mut. 28, 913-921.

Zhou, J., Davey M.E., Figueras, J.B., Rivkina, E., Gilichinsky, D., Tiedje, J.M.. 1997. Phylogenetic diversity of a bacterial community determined from Siberian tundra soil DNA. Microbiol. 143, 3913-3919. 